\title{
UNDERSTANDING OF WISDOM IN THE BOOK OF DANIEL
}

\author{
Peniel C. D. Maiaweng ${ }^{1)^{*}}$ \\ ${ }^{1)}$ Doctor of Theology Sekolah Tinggi Theologia Jaffray \\ ${ }^{*}$ Author's Correspondence:peniel_68@yahoo.com
}

\begin{abstract}
Daniel, Hananiah, Misael, and Azariah were young Jewish people who had been taken to Babylon in captivity. They truly obeyed God in their daily life and did not defile themselves with the king's food and wine. God honored their decision so He gave them wisdom, that is intellectual ability (knowledge and understanding of all kinds of literature and learning and understanding visions and dreams of all kinds). Their response to the wisdom from God was having a good life style, submitting to God, and carrying burdens. To continue the wisdom from God, they lived in unity, depended on God and had God's spirit in them. In doing their job, they spoke with wisdom and tact and worked honestly. In working with the king, they made a courageous decision not to worship the image of god and not to follow the king's command. In the king's palace, Daniel did not think for himself only, but had a burden to pray for Jerusalem, represent his nation before God, and fast for the future.
\end{abstract}

Keywords: God, wisdom, obey, defile, preserve, unity, tact, honest, spirit, burden.

Daniel, Hananya, Misael, dan Azaria adalah pemuda Yahudi yang berada di Babel sebagai tawanan. Mereka benar-benar taat kepada Allah dalam kehidupan sehari-harinya dan tidak menajiskan diri dengan santapan dan minuman raja. Allah menghargai keputusan mereka sehingga Ia memberikan hikmat, yaitu kemampuan intelektual (pengetahuan dan pemahaman berbagai bacaan dan tulisan serta pengetahuan akan berbagai penglihatan dan mimpi. Respons mereka kepada Allah yang telah memberikan hikmat kepada mereka adalah memiliki cara hidup yang benar, hidup dalam ketaatan, dan memiliki beban terhadap orang lain. Untuk mempertahankan hikmat yang mereka miliki, mereka hidup dalam kesatuan, bergantung kepada Allah sepenuhnya, dan hidup yang dipimpin oleh Roh. Dalam melaksanakan tugasnya, mereka berbicara dengan hikmat dan sopan dan bekerja secara jujur. Dalam bekerja bersama raja, mereka juga memiliki keputusan yang kuat untuk tidak menyembah patung yang menyerupai Allah dan tidak mengikuti perintah raja yang mengalihkan keimanan mereka. Di istana raja, Daniel tidak hanya memikirkan dirinya sendiri, tetapi ia memiliki beban untuk mendoakan Yerusalem, mewakili bangsanya di hadapan Allah untuk mengaku dosa mereka, dan berpuasa untuk masa depan bangsanya. 
Kata kunci: Allah, hikmat, taat, menajiskan, mempertahankan, kesatuan, sopan, jujur, roh, beban.

\section{Introduction}

God's will is this: He does what He wants to do to shows His sovereignty for both those who are believers and those who are nonbelievers because He oversees everything, and His power saturates the world that He has created. According to Stephen Miller, "God is portrayed as sovereign, just and powerful. He is in control of the universe and the lives of individuals"1 and "God was the Lord of individuals, nation, and all of history." ${ }^{2}$ Nothing is hidden from Him and no one can act against Him.

In fact, in the book of Daniel, God showed His sovereignty through four young Jewish people: Daniel, Hananiah, Misael, and Azariah (1:6). He did this to reveal His authority and power to the world. The four of them receive wisdom from God, and their wisdom was useful. God used them tremendously to show His purpose for His people (Judah) in the kingdom of Babylon (1:1). God's power was with them to protect them in every decision that they made even those decisions that opposed the king's rule or command. According to Raymond E. Brown and friends, "The author of Daniel ... is particularly concerned with demonstrating the superiority of the wisdom of Israel's God over the merely human wisdom of the pagan, and with showing His immense power, which can and will rescue His faithful ones from their persecutors." ${ }^{3}$ God is always concerned about His chosen ones among the unbelievers and in troubling situations to show His wisdom and power in/through them.

In chapter 2, Nebuchadnezzar dreamed dreams. It troubled his heart and interrupted his sleep (2:1). Then he called the magicians, and the astrologers, and the sorcerers, and the Chaldeans, and asked them to make known the dreams and its interpretation (2:4-5). Nobody could fulfill the king's request. "The Chaldeans answered before the king, and said, There is not a man upon the earth that can shew the king's matter: therefore there is no king, lord, nor ruler, that asked such things at any magician, or astrologer, or Chaldean" $(2: 10-\mathrm{KJV})$. It caused all the wise men to be in trouble. Daniel, Hananiah, Misael, and Azariah were about to be destroyed by the king. In this situation, Daniel met Arioch and

\footnotetext{
1 Stephen Miller, The New American Commentary, volume 18: Daniel (Nashville: Broadman and Holman Publishers, 1994), 47.

${ }^{2}$ Ibid., 57.

${ }^{3}$ Raymond E. Brown, Joseph A. Fitzmyer, and Roland E. Murphy, The Jerome Biblical Commentary (New Jersey: Prentice - Hall, Inc., 1968), 448.
} 
asked him not to kill all the wise men because he would tell the interpretation of the vision to the king (2:24). Daniel did it because God had revealed the mystery of the vision to him (2:19).

In chapter 3, Shadrach, Meshach, and Abednego had not regarded the king. They did not serve the king's gods and worship the golden image which the king had set up (3:12). They were cast into the midst of a burning fiery furnace which was to be heated seven times more than it normal (3:19). God was with them and saved them (3:25). "and the satraps, prefects, governors and royal advisers crowded around them. They saw that the fire had not harmed their bodies, nor was a hair of their heads singed; their robes were not scorched, and there was no smell of fire on them" (3:27 - NIV).

In chapter 5, King Belshazzar's face was pale, his thoughts troubled him, the joints of his loins were loosed, and his knees knocked together (5:6), because he saw fingers of a man's hand that wrote on the plaster of the wall, near a lampstand in the king's palace (5:5). The king called the astrologers, the Chaldeans, and the soothsayers and asked them to tell him the meaning of the writing (5:7), but they could not read the writing and did not know the interpretation (5:8-9). Only Daniel could interpret the writing because he had an excellent spirit, knowledge, and understanding from God (1:17; 5:12, 17-28).

In chapter 6, Daniel was thrown into the lions' den, because he did not obey the king's decree that was signed by the king himself $(6: 8,11$ 12). God had sent His angel and had shut the lions' mouths so that they did not hurt Daniel (6:22).

Because of the wisdom that God had given them, they had God's blessing in all of their responsibilities. Daniel was the best interpreter (2:30-45; 4:19-27; 5:7-14), had a high position, was lavished with many gifts, ruled over the country, and was placed in charge of all its wise men (1:48). Daniel was clothed in purple, a gold chain was placed around his neck, and he was proclaimed the third highest ruler in the kingdom (15:29). Daniel even prospered during the reign of Darius and Cyrus (6:29). Shadrach, Meshach, and Abednego became administrators over the province of Babylon (2:49), and the king promoted them in the province in Babylon (3:33).

God protected Daniel, Shadrach, Meshach, and Abednego in the bad situations that they faced because they lived, worked, and made decisions based on the wisdom that they had from God. "The whole episode reveals that Yahweh was fully able to act in behalf of his faithful ones even in their captivity and distress in Babylon." ${ }^{4}$ And everything

${ }^{4}$ Zdravko Stefanovic, "Daniel: A Book of Significant Reveals," Andrews University Seminary Studies, 1992, Vol. 30, No. 2, 141. Diakses 10 Maret 2016, http://www.auss.info/ auss_publication_file.php?pub_id=845\&journal=1\&type=pdf. 
that Daniel and his friends had and did was a witness about God (cf. $2: 28,47 ; 3: 28-29 ; 4: 32-35 ; 5: 22-28 ; 6: 22-23)$ that showed God's sovereignty in individuals that influenced all the nations.

\section{The Meaning of Wisdom}

The word "wisdom" is translated from the Hebrew word khokma, which means technical skill or aptitude (1 Kings 7:14) and experience or good sense (2 Sam. 20:22). ${ }^{5}$ Wisdom also means shrewdness, prudence (in religious affairs), and ethical and religious wisdom. "Wisdom isn't simply intelligence or knowledge or even understanding. It is the ability to use these to think and act in such a way that common sense prevails and choices are beneficial and productive." According to the Bible, "The fear of the LORD is the beginning of wisdom, and knowledge of the Holy One is understanding" (Proverbs 9:10). This means wisdom begins and ends with the fear of the Lord. ${ }^{8}$ Wisdom is God's given ability to act, talk, think, work, and make decisions wisely and its results are for the goodness of the person, the organization, the people, and the glory of God. Wisdom according to the book of Daniel is:

1. Intellectual ability, that is knowledge and understanding of all kinds of literature and learning (1:17) and understanding visions and dreams of all kinds (1:17).

2. Having a good lifestyle, such as speaking with wisdom and tact (2:14) and working honestly (6:4).

3. Submitting, such as depending on God in prayer (2:17-18), not worshiping the image of gold (3:12), and not following the king's command against God (6:13).

4. Carrying burdens, such as praying for Jerusalem (6:10), representing the nation before God, and fasting for the future (10:1-3).

And also "A number of texts emphasize that Danielic wisdom indeed "extends over the secrets of the future": Dan 2:31ff; 4:16ff; 5:13ff; 7:lff; 8:lff;

${ }^{5}$ W. L. Holladay (editor), A Concise Hebrew and Aramaic Lexicon of the Old Testament, Based upon the Lexical Work of Ludwig Koehler and Walter Baumgartner (Boston: Brill Academic Publishers, 1997), s.v. "wisdom."

${ }^{6}$ James Strong, Strong's Exhaustive Concordance of the Bible, Reference Library Edition. (Iowa Falls, Iowa: World Bible Publishers, no year), s.v. "wisdom."

${ }^{7}$ Jack Wellman, "What Is The Bible Definition Of Wisdom? How Are We Wise In God's Eyes?" diakses 2 Maret 2016, http://www.patheos.com/blogs/christiancrier/ 2015/05/22/what-is-the-bible-definition-of-wisdom-how-are-we-wise-in-gods-eyes/

${ }^{8}$ Ibid. 
9:20ff; 10:1ff." 9 Therefore, wisdom in the book of Daniel is ability form God to know things which will happen in the future based on His plan and sovereignty.

\section{The Basis of Wisdom (1:8)}

Daniel made a decision to keep himself holy. "But Daniel purposed in his heart that he would not defile himself with the portion of the king's meat, nor with the wine which he drank: therefore he requested of the prince of the eunuchs that he might not defile himself" (1:8 - KJV). Hananiah, Mishael, and Azariah also made the same decision as Daniel (1:11, 14, 17-20). They lived in a competitive culture in Babel, but they conducted themselves as the servants of God who devoted themselves to God and refused the king's food. ${ }^{10}$ The reasons Daniel and his friends did not defile themselves are:

First, many of the foods eaten at the Babylonian court ... would have been unclean according to the law of Moses (c.f. Lev. 11 and Deut. 14), either inherently or because they were not prepared properly; for example, the blood might not have been drained from meat (cf. Lev. 17:13-14). To eat such food might not have been a sin as for an Israelite and would have rendered the individual ceremonially unclean before God. Second, the meat and wine would have been undesirable because a portion of it was ... first offered sacrificially to the Babylonian gods before being sent to the king and was therefore associated with idolatrous worship. ${ }^{11}$

Perhaps because of these possibilities, they were not interested in the food and the wine that were prepared for them in the king's palace. Even though they were far from their home, they had to maintain the Jewish law that they followed in their own country. They still obeyed God rather than enjoyed the king's food and wine. For them, "The consciousness that their God was right and kind is requiring this discipline of the appetites, increased their reverence and love, made them

\footnotetext{
${ }^{9}$ Michael K. Wilson, The Book of Daniel: The Lives of the Wise in An Anti-God World, 2010, 189, diakses 10 Maret 2016, https://kb.osu.edu/dspace/bitstream/handle/181l/58706 /HAR_v9_373.pdf?sequence=1

${ }^{10}$ Willem A. VanGemeren, Penginterpretasian Kitab Para Nabi (Jakarta: Momentum, 2007), 371.

${ }^{11}$ Stephen R. Miller, 66-67. Compare to Lynne Newell, Seri Tafsiran Alkitab: Kitab Daniel (Malang: SAAT, 2000), 69-70.
} 
more resolute in their heavenly allegiance." ${ }^{12}$ They were really faithful to God and they only wanted to please Him.

According to J. E. H. Thomson and W. F. Adeney, "Hence Daniel and others were bound to an earlier and higher allegiance, which they had resolved not to violate. They had no power of choice left. In religious duty they were bound to the King of heaven. They were willing to render unto Caesar those things which were Caesar's, but they were determined also to render unto God the things which were God's." ${ }^{13}$ They did it without reservation. ${ }^{14}$ Their decision to obey God was the highest priority. They had no other choice. Even though they had to risk their lives and jobs, they just obeyed God. They believed that work, knowledge, and health were from God, so they were courageously chose to obey God.

Therefore, the basis of wisdom in the book of Daniel was the decision not to defile their bodies with sacrifices that were offered to gods and not to partake in idolatrous worship. Daniel and his prioritized living in holiness wherever they were. Even in difficult situations, they had to consistenly do the law of God.

\section{The Source of Wisdom (1:17)}

Daniel, Hananiah, Mishael, and Azariah were people who believed God. They were captives, but spiritual discipline and moral life based on God's law became their priority. ${ }^{15}$ They did not defile themselves with the king's food and wine, and God blessed them with special gifts. "To these four young men God gave knowledge and understanding of all kinds of literature and learning. And Daniel could understand visions and dreams of all kinds" (1:17 - NIV).

God paid attention to Daniel and his friends and gave them knowledge and understanding that were crucial for them in doing their jobs. It was not because they studied the learning and the tongue of the Chaldeans in king's palace, but only God gave them knowledge and understanding of all kinds of literature and learning. Ronald S. Wallace mentioned that their submission not to define themselves with the food and wine became the blessing of having knowledge and understanding. ${ }^{16}$

\footnotetext{
${ }^{12}$ J. E. H. Thomson and W. F. Adeney, "Daniel," in H. D. M. Spence and Joseph S. Exell, The Pulpit Commentary, Volume 13: Daniel, Hosea, Joel (Grand Rapids, Michigan: William B. Eerdmans Publishing Company, 1981), 35.

${ }^{13}$ H. D. M. Spence and Joseph S. Exell, 34.

${ }^{14}$ Ibid., 35.

${ }^{15}$ Ronald S. Wallace, Daniel: Kedaulatan dan Kasih Allah Berseri Kendati Situasi Negeri Ngeri Tak Terperi (Jakarta: Yayasan Komunikasi Bina Kasih, 2010), 48.

${ }^{16}$ Ibid., 49.
} 
"Knowledge has to do with reasoning skills and thought processes. They were able to think clearly and logically. Understanding has to do with insight. This points to their ability to discern the nature of things clearly and to interpret them in their own light." ${ }^{17}$ God gave them knowledge and understanding for the purpose of doing their job well and becoming God's witnesses to Nebuchadnezzar, all magicians, and people in other religions in Babylon.

Especially for Daniel, "The fact that God gave Daniel the ability to understand and interpret visions and dreams (Dan. 1:17) meant that throughout Nebuchadnezzar's long reign he depended on Daniel for understanding future events, revealed through dreams and visions." ${ }^{\text {18 }}$ In chapter 2 and 4-5, Daniel used his ability to understand and interpret visions and dreams of king Nebuchadnezzar (2:34-45; 4:19-27) and also to interpret the writing that was seen by king Belshazzar (5:17-29).

In having knowledge and understanding of all learning and wisdom, Daniel, Hananiah, Mishael, and Azariah were the most faithful servants. "The king talked with them, and he found none equal to Daniel, Hananiah, Mishael and Azariah; so they entered the king's service. In every matter of wisdom and understanding about which the king questioned them, he found them ten times better than all the magicians and enchanters in his whole kingdom" (1:19-20). Nobody could compare to them. They were better than all the wise men in the kingdom of Babylon.

Therefore, the knowledge and the understanding that Daniel and his friends had was not their own achievement, but they received it freely from God when they preferred to obey God. Nebuchadnezzar recognized their wisdom and understanding. God made them to become more excellent than others. Not one of the magicians and enchanters in Babylon were like them.

\section{The Preservation of Wisdom}

To preserve the wisdom, Daniel and his friends lived in unity, depended on God (2:17-18), and the spirit of God lived in them (4:8; 5:11, 14).

\section{Unity and Dependence on God}

In chapter 2, king Nebuchadnezzar had dreams. It trouble his mind and he could not sleep (2:1). He called magicians, enchanters, sorcerers and astrologers and asked them to tell him what he had dreamed (2:2).

\footnotetext{
${ }^{17}$ John F. Walvoord and Roy B. Suck, The Bible Knowledge Commentary Old Testament (Wheaton, Illinois: Victors Book, 1986), 1331.

${ }^{18}$ John F. Walvoord and Roy B. Suck, 1332.
} 
Actually, the king did not ask them for the interpretation only, but also the dream itself. The king's request disturbed the magicians, enchanters, sorcerers and astrologers because they could not tell the dream and its interpretation (2:3). The astrologers said, "There is not a man on earth who can do what the king asks! No king, however great and mighty, has ever asked such a thing of any magician or enchanter or astrologer. What the king asks is too difficult. No one can reveal it to the king except the gods, and they do not live among men" (2:10-11 - NIV). No one could answer. This made the king so angry that he issued the decree to kill all the wise men in Babylon (2:12-13). Daniel and his friends were threatened with death (2:13). The commander of the king's guard, Ariokch, went out to kill the wise men, but Daniel met him and asked him with wisdom and tact about the king's decree (2:14-15). After that, Daniel met the king and requested him time in order that he might reveal the dream and its interpretation (2:16).

In this situation, "Then Daniel returned to his house and explained the matter to his friends Hananiah, Mishael and Azariah. He urged them to plead for mercy from the God of heaven concerning this mystery, so that he and his friends might not be executed with the rest of the wise men of Babylon" (2:17-18). They lived together because they wanted to take care of their pure lives before God. ${ }^{19}$ Therefore, Daniel asked his friends to look for God's help, depend on Him in prayer, and plead for His mercy for the king's dream and its interpretation. "Daniel demonstrated real communication with the high God far transcending the merely human wisdom of the rest of diviners." ${ }^{20}$ There was no other source of help for Daniel and his friends. They knew that only God could help them.

Being together with his friends in this situation, "Daniel's heart was not excited with selfish ambition to secure the honour of triumph for himself. He solicited the aid of his companions in this holy task, and addresses them by their 'union in strength' in prayer, as much as in tail." ${ }^{21}$ Daniel was not an egocentric man. He involved his friends to solve the problem that they faced. They unified themselves and had unity in prayer to plead for God's mercy on them. Only God's mercy could release them from the king's decree.

Consequently, "During the night the mystery was revealed to Daniel in a vision. Then Daniel praised the God of heaven" (2:19 - NIV). God fulfilled their request. God revealed the dream and its interpretation to Daniel in a vision. Even though Daniel and his friends had the ability

\footnotetext{
${ }^{19}$ Lynne Newell, 83.

20 Frank E. Gaebelin, The Expositor's Bible Commentary, Vol. 7 (Grand Rapids, Michigan: Zondervan Publishing House, 1985), 61.

${ }^{2 \mathrm{I}}$ H. D. M Spence and Joseph S. Excell, 89.
} 
knowledge and understanding of all kinds of literature and learning, even Daniel had the ability to understand all visions and dreams, they still depended on God only. Lastly, Daniel told the king the dream and its interpretation (2:20-45).

For Daniel himself, God honored his actions what he did. The Bible says, "Do not be afraid, Daniel. Since the first day that you set your mind to gain understanding and to humble yourself before your God, your words were heard, and I have come in response to them" (10:12). Therefore unity and dependence on God in prayer became their priority to solve the problem. And the wisdom that God gave them was to fulfill the needs of their job and to reveal the greatness of God to the nation.

\section{The Indwelling of the Spirit of Holy God}

Nebuchadnezzar said, "Finally, Daniel came into my presence and I told him the dream. (He is called Belteshazzar, after the name of my god, and the spirit of the holy gods is in him)" (4:8 - NIV). The queen of Belshazzar also said, "There is a man in thy kingdom, in whom is the spirit of the holy gods; and in the days of thy father light and understanding and wisdom, like the wisdom of the gods, was found in him ... I have even heard of thee, that the spirit of the gods is in thee, and that light and understanding and excellent wisdom is found in thee" (5:11, $14-\mathrm{KJV})$.

Nebuchadnezzar and the queen of Belshazzar recognized that Daniel was a unique person because his name was the name of Babylon's god, the spirit of the holy gods was in him, his wisdom was like the wisdom of gods, and the wisdom of gods was found in him. That was the reason why Daniel could interpret dreams and visions. He was among the wise men in Babylon, but he was the best.

Whatever the opinion about gods who lived in Daniel based on Nebuchadnezzar and the queen of Belshazzar's understanding, Daniel himself proved that God lived in him. God caused the official to show favor and sympathy to Daniel (1:8); God gave knowledge and understanding of all kinds visions and dreams (1:17); God revealed the vision of Nebuchadnezzar to Daniel (2:19); God revealed the interpretation Nebuchadnezzar's dream to Daniel (4:19-27); God revealed the meaning of writing on the plaster of the wall (5:17-28); and God protected Daniel in the lions' den (6:16-25).

Therefore, the narrator and characters in the book of Daniel realized that the God of Daniel is the holy God. And the key for Daniel to impart this wisdom was God lived in him, gave him wisdom and understanding, and worked through him so he could interpret dreams and visions. 


\section{Relationship of Wisdom and Job Performance}

Daniel and his friends worked among people who were not from the same nations and religion. They had wisdom from God and they did their best in the king's palace. They had good words (2:14) and good works $(6: 4)$.

\section{Speak with Wisdom and Tact}

Daniel solved the problem that he had by speaking with wisdom and tact. "When Arioch, the commander of the king's guard, had gone out to put to death the wise men of Babylon, Daniel spoke to him with wisdom and tact" (2:14 - NIV). Daniel was a humble and polite person. He asked permission before the king's guard to meet the king for the answer of the dream. "Daniel spoke of appropriateness, suitability. Daniel replied wisely and in good taste, in keeping with the occasion and importance of visitor." 22 Daniel showed his wisdom by action and speaking, and these resulted in the good reponse of the king's guard and the king himself to allow him to tell the dream and its interpretation.

\section{Working Honestly (6:4)}

Daniel was a worker with integrity. It was recognized by the administrator and the satraps, "At this, the administrators and the satraps tried to find grounds for charges against Daniel in his conduct of government affairs, but they were unable to do so. They could find no corruption in him, because he was trustworthy and neither corrupt nor negligent" (6:4 - NIV). They even said, "We will never find any basis for charges against this man Daniel ..." (6:5 - NIV).

Daniel consistently obeyed God in all areas of his life, such as high administrator in the kingdom. In fact, "Daniel handled his duties in a faithful manner (trustworthy) - he was neither politically 'corrupt' (dishonest) not 'negligent' in the performance of his work." ${ }^{23}$ His fellow workers did not find any mistakes in his job. He worked honestly and he was trusted by the king.

Daniel really knew that his job was also from God and the wisdom that he had also from God so he did his responsibility as administrator without any corruption and negligence. He worked among the gentiles but he worked honestly. He did his job in the kingdom and for the king, but actually, he did his job as a service to God. That was why he worked without any corruption and negligence.

\footnotetext{
${ }^{22}$ L. Wood, A Commentary on Daniel (Grand Rapids, Zondervan, 1973), 56. Taken by Stephen R. Miller, 84.

${ }^{23}$ Miller, 179.
} 


\section{Relationship of Wisdom and Submission}

Daniel and his friends had wisdom from God. As a result, they had to obey God rather than the images of gods (3:12). Even though Daniel was tempted to submit himself to the king and the result was losing his job or death, obeying God in all situations was his only choice (6:12).

\section{Do Not Worship the Image of A god}

In having wisdom from God, Shadrach, Meshach and Abednego proved that they obeyed God in all areas of their lives, so they did not worship the image of a god. "But there are some Jews whom you have set over the affairs of the province of Babylon, Shadrach, Meshach and Abednego who pay no attention to you, O king. They neither serve your gods nor worship the image of gold you have set up" (3:12 - NIV). It was rebellion against the king and his rule. It would bring Shadrach, Meshach and Abednego to the threat of death, but it was their decision to make. They prioritized worshipping God rather than worshipping the image of a god. They said, "O Nebuchadnezzar, we do not need to defend ourselves before you in this matter. If we are thrown into the blazing furnace, the God we serve is able to save us from it, and he will rescue us from your hand, $\mathrm{O}$ king. But even if he does not, we want you to know, O king, that we will not serve your gods or worship the image of gold you have set up" (3:16-18 - NIV). Shadrach, Meshach and Abednego believed that God would save them, but if God did not save them, they were ready to die rather than follow king's command. Walvoord and Zuck wrote, "One who obeys God is not presuming when he expects God to protect and deliver him. Obeying God was more important than life to those three, ... they still obey Him. Therefore they refuse to serve Nebuchadnezzar god's (or worship the image he made, possibly meaning to worship him as god) even if it meant they would die." ${ }^{24}$ They had no other option. They only worshipped God. So, even though the result of their decision was possible death, they did not worry about that. They preferred to obey God than serve and worship the images of god. They knew that if God could give them health, understanding, and knowledge, God also could help them from the threat of death. It was their faith. In fact, God protected them (3:24-27), they became witnesses for the king and the whole kingdom (3:28-29), and God blessed them with high positions in the kingdom (3:30).

\footnotetext{
${ }^{24}$ Walvoord and Zuck, 1339.
} 


\section{Do Not Follow King's Command}

Daniel was a good man. He was a successful worker. He was trustworthy and neither corrupt nor negligent (6:4). His fellow workers, the administrators and the satraps, tried to find fault with him, but they could not find any. They made a plan that could trap Daniel. They asked king Darius to issue a decree that in thirty days if anyone prays to any god or man will be thrown in to the lions' den (6:6-7). The decree could not be altered in accordance with the law of the Medes and Persians, and could not be replaced (6:8).

When Daniel heard that the decree had been published, he went home. In his upstairs room, where the windows opened to Jerusalem, three times a day he got down on his knees, prayed, and gave thanks to God, as he usually did (6:10). The men went to Daniel's house and found him praying and seeking God (6:11). They met the king and reported what Daniel did and the king said that Daniel must be punished according to the decree (6:12).

They said to the king, "Daniel, who is one of the exiles from Judah, pays no attention to you, $\mathrm{O}$ king, or to the decree you put in writing. He still prays three times a day" (6:13 - NIV). Daniel paid no attention to the king's decree. "Daniel made no attempt to hide his devotion to or his dependence on God, even though it now means disobeying a governmental decree (cf. Ac. 5:29). Daniel would not and could not look to Darius for the guidance and strength he knew God alone could supply." ${ }^{25}$ He just bowed down before God, spent time with God in prayer, and gave thanks to God. As the result, God protected him in the den of lions (6:19-22).

\section{Relationship of Wisdom and Burden}

Daniel, who possessed wisdom from God, had a burden for others. The responsibilities were praying for his own nation (6:10), representing his own people before God (9:1-3), and fasting for the future (10:1-3).

\section{Pray for Jerusalem}

Daniel was out of his country, lived at the king's palace, and had a high position in the kingdom of Babylon and Medes/Persians, but he had burden for his nation. He showed it by praying for Jerusalem. "Now when Daniel learned that the decree had been published, he went home to his upstairs room where the windows opened toward Jerusalem. Three times a day he got down on his knees and prayed, giving thanks to his God, just as he had done before" (6:10). Daniel had the habit to pray three times a day. Actually he

\footnotetext{
${ }^{25}$ Walvoord and Zuck, 1388.
} 
was a busy man but he spent time to worship God, pray, and give thanks. All people knew his habit about praying three times a day. The focus of his prayer was Jerusalem. He prayed for Jerusalem and its restoration. For Daniel, "Praying toward Jerusalem was a touching proof of his true patriotism." 26 He really loved his people and its place. Even though he faced death he did pray for his own country so the people and the city could be saved by God.

\section{Represent His Nation before God}

Daniel had a burden for Jerusalem. He was a man who paid attention to the Scripture about Jerusalem. During the time the Jews were in Babylon, Daniel counted the years according to Jeremiah's prophecy. He knew that the desolation of Jerusalem would be ended and God would fulfill the prophecy.

In the first year of Darius son of Xerxes (a Mede by descent), who was made ruler over the Babylonian kingdom in the first year of his reign, I, Daniel, understood from the Scriptures, according to the word of the LORD given to Jeremiah the prophet, that the desolation of Jerusalem would last seventy years. So I turned to the Lord God and pleaded with him in prayer and petition, in fasting, and in sackcloth and ashes (9:1-3 - NIV).

Daniel felt the responsibility to his nation and his land to be restored. When he understood the prophecy, he represented his nation before God. Spence and Exell wrote, "Daniel's study of the scripture led him to turn to God and to pray a prayer of confession (vv. 3-14) and petition (vv. 15-19), with fasting, wearing sackcloth and/or ashes was evidence of mourning in grief of repentance." ${ }^{27}$ He had great passion for Jerusalem, "... he identified himself with his people." 28 He took responsibility and put it on himself for the sake of his own land and his own people because he really loved them.

\section{Fasting for the Future}

Daniel did not focus on Jerusalem only, but also the future. He took seriously what God had revealed to him. "In the third year of Cyrus king of Persia, a revelation was given to Daniel (who was called Belteshazzar). Its message was true and it concerned a great war. The understanding of the message came to him in a vision. At that time I, Daniel, mourned for three weeks. I ate no choice food; no meat or wine touched my lips; and I used no lotions at all until the three weeks were over" (10:1-3 - NIV).

\footnotetext{
${ }^{26}$ H. D. M. Spence and Joseph S. Exell, 197.

${ }^{27}$ Walvoord and Zuck, 1359.

${ }^{28}$ Miller, 245.
} 
After he received a vision about war and great hardship, he knew that it would happen to his nation. He interceded for his nation. "He mourned in Israel's sorrow." ${ }^{29}$ He mourned and fasted for three weeks. No food, no meat, no wine touched his lips and he used no lotion. He did it for the sake of the future of his nation.

\section{Conclusion}

God has wisdom and His people can have it as well. It depends on consistently they live in following God's word in their lives. Wisdom is not for the purpose of having a good spiritual life, but as the result of living in holiness before God. The wisdom that God gave Daniel, resulted in intellectual ability, knowledge and understanding of all kinds of literature and learning and understanding visions and dreams of all kinds (1:17). The responsibilities are living in unity (2:17), depending on God (2:18), living with the Spirit of God $(4: 8,5: 11,14)$, speaking with wisdom and tact (2:14), working honestly (6:4), not worshipping the image of a god (3:12), not following the king's command, praying for Jerusalem (6:10), representing the nation before God (9:1-3), and fasting for the future of own people (10:1-3). And truly, in the book of Daniel, “... the most important purpose of God-given wisdom is to reveal that God is the ultimate ruler who controls the course of history" 30 because He is God of all nations and everything is in His control.

The implications for believers are: Firstly, God's sovereignty controls everything, every person, and every nation according to His will and He controls everything that He has created for His glory. He can use His people and work through them for His purpose.

Secondly, God has wisdom, power, mercy, and authority. God's people can have it if they obey Him and be humble before Him. So, the basis of wisdom is submission before God.

Thirdly, Prayer is an instrument that God has given His people to unify themselves with Him and to preserve the wisdom that they have from God.

Fourthly, God's people have to confess their sins and ask God for forgiveness because He is holy. When God's people confess their sins, they pay attention to His holiness. People who have wisdom know that when they do sin, they have to look for a solution from God for their forgiveness.

Fifthly, God's people are tempted in whatever situation they find themselves to bow to human desires that lead to sinning against God.

\footnotetext{
${ }^{29}$ Spence and Exell, 277.

${ }^{30}$ Wilson, 197.
} 
Even though it is worse for them, but they have to choose to obey God rather than others.

Sixthly, God will make a way to prepare the future life of His people and He can use them as His instrument to do His will. The demand is to obey Him in every situation of life, do the job honestly and in the right way, and look for Him in every area of life. Even though they are intelligent people, they have to depend on God for His guidance so He will lead them to do good things in their lives.

Seventhly, Whatever God's people do and wherever they are, they must be a witness for others through their speaking, action, and life style. They must ask the Holy Spirit to lead day by day to do God's will, so they will be like Christ.

\section{Bibliography}

Biblia Hebraica Stutgartensia. Stuttgart: Deutsche Bibelgesellschaft, 1990. Bible Works 7.

Brown, Raymond E., Joseph A. Fitzmyer, and Roland E. Murphy. The Jerome Biblical Commentary. New Jersey: Prentice - Hall, Inc., 1968.

Gaebelin, Frank E. The Expositor's Bible Commentary, Vol. 7. Grand Rapids, Michigan: Zondervan Publishing House, 1985.

Holladay, W. L. (editor). A Concise Hebrew and Aramaic Lexicon of the Old Testament, Based upon the Lexical Work of Ludwig Koehler and Walter Baumgartner. Boston: Brill Academic Publishers, 1997. Bible Works 7.

James, Strong. Strong's Exhaustive Concordance of the Bible, Reference Library Edition. Iowa Falls, Iowa: World Bible Publishers, n.d.

Miller, Stephen. The New American Commentary, volume 18: Daniel (Nashville: Broadman and Holman Publishers, 1994.

Newell, Lynne. Seri Tafsiran Alkitab: Kitab Daniel. Malang: Literatur SAAT, 2000.

Spence, H. D. M., Joseph S. Exell, The Pulpit Commentary, Volume 13: Daniel, Hosea, Joel. Grand Rapids, Michigan: William B. Eerdmans Publishing Company, 1981.

Stefanovic, Zdravko. "Daniel: A Book of Significant Reveals," Andrews University Seminary Studies, Vol. 30, No. 2 (1992). Diakses 10 Maret 2016.http://www.auss.info/auss_publication_file.php?pub_id=845\&j ournal=1\&type=pdf

Wallace, Ronald S. Daniel: Kedaulatan dan Kasih Allah Berseri Kendati Situasi Negeri Ngeri Tak Terperi. Jakarta: Yayasan Komunikasi Bina Kasih, 2010.

VanGemeren, Willem A. Penginterpretasian Kitab Para Nabi. Jakarta: Momentum, 2007. 
Walvoord, John F., and Roy B. Suck, The Bible Knowledge Commentary Old Testament. Wheaton, Illinois: Victors Book, 1986.

Wellman, Jack. "What Is The Bible Definition Of Wisdom? How Are We Wise In God's Eyes?" http://www.patheos.com/blogs/christiancrier/ 2015/05/22/what-is-the-bible-definition-of-wisdom-how-are-wewise-in-gods-eyes/

Wilson, Michael K. The Book of Daniel: The Lives of the Wise in An Anti-God World, 2010. Diakses 10 Maret 2016. https://kb.osu.edu/dspace/ bitstream/handle/181l/58706/HAR_v9_373.pdf?sequence=1. 